This article was downloaded by: [New York University] On: 13 January 2015, At: 17: 14

Publisher: Routledge

Informa Ltd Registered in England and Wales Registered Number: 1072954 Registered office: Mortimer House, 37-41 Mortimer Street, London W1T 3J H, UK

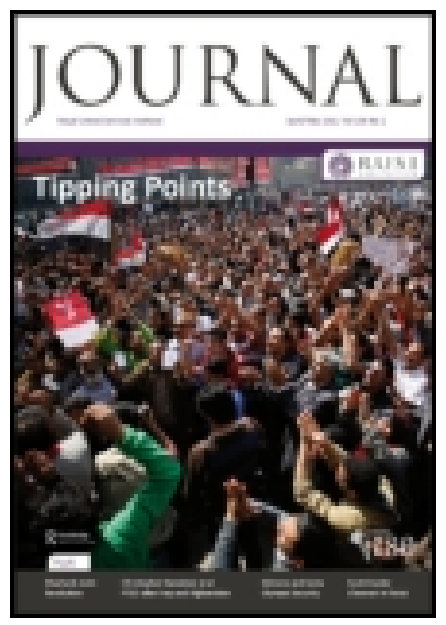

Royal United Services Institution. J ournal

Publication details, including instructions for authors and subscription information: http:// www. tandfonline.com/ loi/rusi 19

\title{
Ancient Naval Tactics. Part II
}

Rev. Edmond Warre M.A.

Published online: 11 Sep 2009.

To cite this article: Rev. Edmond Warre M.A. (1876) Ancient Naval Tactics. Part II, Royal United Services Institution. J ournal, 20:88, 608-631, DOI: 10.1080/03071849709416325

To link to this article: http://

dx. doi.org/ 10.1080/03071849709416325

\section{PLEASE SCROLL DOWN FOR ARTICLE}

Taylor \& Francis makes every effort to ensure the accuracy of all the information (the "Content") contained in the publications on our platform. However, Taylor \& Francis, our agents, and our licensors make no representations or warranties whatsoever as to the accuracy, completeness, or suitability for any purpose of the Content. Any opinions and views expressed in this publication are the opinions and views of the authors, and are not the views of or endorsed by Taylor \& Francis. The accuracy of the Content 
should not be relied upon and should be independently verified with primary sources of information. Taylor and Francis shall not be liable for any losses, actions, claims, proceedings, demands, costs, expenses, damages, and other liabilities whatsoever or howsoever caused arising directly or indirectly in connection with, in relation to or arising out of the use of the Content.

This article may be used for research, teaching, and private study purposes. Any substantial or systematic reproduction, redistribution, reselling, loan, sub-licensing, systematic supply, or distribution in any form to anyone is expressly forbidden. Terms \& Conditions of access and use can be found at http://www.tandfonline.com/page/terms-andconditions 


\section{LECTURE.}

Friday, June 2nd, 1876.

Rear-Adniral T. A. B. SPRATT, C.B., F.R.S., in the Chair.

\section{ANCIENT NAVAL TACTICS.}

PART II.

By the Rev. Ebjoxd Warre, Ml.A., Eton College.

Iv resuming the subject of Ancient Naval Tactics this afternoon, I propose to follow the lines laid down in my first lecture, and to treat in the first place of the renpons of offence used in ancient ressels, and of the means employed to meet them. The consideration of the pro. gressive improvements and alterations made for offensive and defen. sive purposes in the construction of vessels, and their armament will naturally bring us to our main and proper topic-the naval tactics of the ancients. These will fall under two heads: minor tactics, which concern the handling of a single ressel, and grand tactics, which concern the handling of fleets. For illustration, we shall have to refer to incidents of Greek and Roman warfare recorded by ancient authors, and it is possible, though I am not very sanguine upon this point, that the consideration of those ancient conflicts may be suggestive to those whose attention is given to the important subject of modern naval tactics, which have at least the use of the ram in common with those of the ancient world. Lastly, if time allows, we may glance at the growth and decline of the ancient marine, and the causes that produced these effects, and attempt to draw some comparison between the size and tonnage of ancient and modern fleets, and the number of men employed in them respectively.

Of the weapons of offence with which ancient ships were armed, the ram, or, to speak more correctly, the beak, was for a long period the most formidable, and that from very early times. If we are to believe Pliny, the invention was due to one Piseus, a T'uscan pirate chief, who, according to a quotation given from Janetho, was master of Italy for a considerable time. There does not, however, seem to be much in support of this statement; all the other evidence we have points to Egypt or Phonicia, the east, and not the west, as the cradle of this 
inrention. There is, as $I$ hare already said, no direct mention of the beak in Homer, who, however tells us how

\author{
" round the ressel's prow (orkipp) \\ The dark wares loudly roared as on she rushed \\ Skimming the seas and cut her watery way," 1
}

a passage which seems to me to indicate that an advance in build from the earlier type had already been arrived at in Homer's time. The later poets, indeed, speak of the war-vessels of Greeks as armed in Trojan times with brazen prows, and in a fragment of Eschylus,

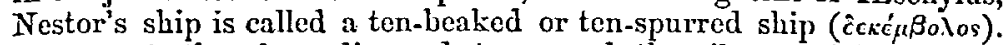
I am not, therefore, disposed to regard the silence of Homer as proving that the beak was unknown to the Greeks in Trojan times.

We hare in Diodorus a statement regarding a conflict which has been claimed as the most ancient sea-fight whereof this world holds recard, to the effect that "Semiramis, when she reached the Indus, " found the King's fleet prepared for battle, put her soldiers on board " her own flotilla, attacked him, and after a desperate struggle, in "which nigh a thousand ressels were sunk, won the victorg." This statement finds support in several other passages, and amongst them in one from Suidas, in which he says that "Somiramis had con" structed in Bactria 3,000 vessels of war. with brazen beaks " ( $\left.\chi a \lambda_{\kappa} \dot{\epsilon} \mu, \beta o \lambda o r\right)$, the crews for which were furnished from. Syria, Phoc" nicia, \&ggpt, Cyprus, and Cilicia." Such legendary splendour surrounds Semiramis that one is quite sorry to find her either sublimated into a solar myth, or reduced by a prosaic inscription to the position of consort to Pul, King of Assyria, and her date brought down from the time of Abraham, assigned to her.by Eusebius and Augustine, to the much later figure of 740 B.c. There is in the British Mluseum a very spirited representation of an $\Lambda$ ssyrian wargalles, moring at full speed, such a galley as we may imagine the warrior Queen to have employed. The beak in this case has the character of a pointed spur attached to the bows of the ressel at the water-line.

If ancient authors fail to tell us any more than this concerning the invention of the ram, we must turn for information to those carly representations of ressels which the venerable and everfresh antiquity of Egypt has preserved for us.

In his earliest efforts to construct a ship from sawn planks, man found himself assisted by the natural tendencies of the material $\mathrm{cm}$ ployed. The natural currature of planks fastened together in the middle, on a curred pair of ribs, which would represent what we should call the midship section of the ressel, determined in the first instance to a great extent the shape of the bow and stern. These in the earliest vessels were nearly alike, a featnre which though it obtained in trading vessels to a late period, is wrongly attributed to all ancient vessels by MIr. Smith, of Jordan Hill. We see this carly type clearly shown in the representations which so often occur on Egsptian sarcophagi of the craft in which the souls of the dead are

vol. $x$. 1 Il., i, 4S2. Lord Derbj's Trans. 
being carried on their last voyage by attendant deities. ${ }^{2}$ These are worthy of our attention, not only as being extremely ancient, but as giving us a point of departure in the history of the construction of the beaked prow. Both ends of the boat are alike sharp, and upon both the superstructure is carried in a curve backwards and upwards so as to ufford protection from the wares, presenting us with the rudimentary outline of that which was afterwards to develop into prow and poop respectively. The top of the structure abore the prow is often flattened and corered in, and upon it is seated a griding deity, the prototype of the "look-ont" man at the bows in later time. The keel, as is evident, has great camber fore and aft, bad for specd, good for turning quickly, useful in the case of a boat stecring down the current of father Nile, but not so advantageous when some distant village had to be reached across his mide inundations. The loi d'épargne, the law of least effort, which as part of the many-sided necessity that rules so largely in human affairs, is the mother of manifold invention, would soon, where human labour at the oar was too lavishly expended, teach men, as they built their vessels, to decrease the upward curve towards the bow, and to bring it down nearer and nearer to the water, by fastening the planks together, end to end vertically. Thus by degrees the forward part of the ressel was immersed in its whole length, while the high stern preserved the advantage of rapid turning-power. Similarly when the vessel was used for purposes of attack, and the experience of charging an enemy's ship had been ensued, the adaptation of the bow for this purpose by prolonging it with projecting timbers would naturally suggest itself. The subsequent addition of a metal boss or pointed share, so as to inflict either a racking or piercing blow, was an obvious improvement to those whose business it was to plough the main. But the earliest type of artificial beak consisted simply in the prolongation of the keeltimber beyond the point at which the stem of the vessel was carried upwards.

That all these successive improrements in construction were due in the first place to the Egyptians is in a high degree probable. That they possessed a fleet and navigated the Mrediterranean and Red Seas at a vers carly period is tolerably certain, even if the statement made by the priests to Herodotns (Book II, 102) concerningr Sethi or Sethosis, that he navigated the Erythrean Sea or Indian Ocean in a fleet of ships of war, be fabulons. The legends of Danäus and Egyptus connect Egsptian maritime enterprise with Greece, and in a remarkable passage Euripides (Troades 127) calls the ropes of the Greek ressels the "twisted teaching of Egrpt."

Did the Phonicians-(the chief rivals of the Greeks in the carrying trade of the MIediterranean, and certainly their teachers in many things connected with ship building from very carly times)-did the Phocnicians in the first instance ome their knowledge of ship-building to Eggpt, or was it of native growth? The earliest representations of Phenician ressels that we have are of a much later date than those on Fgyptian monuments, and are many stages in adrance of them in

1 See Plate XX. 
form. They are in most respects similar to the early Greek types, which probably were borrowed from them. In these, both on coins and vases, we have the projecting beam for a beak, and a nearly straight bow and forecastle rising above it. 'The coin of Phaselis, a town of Lycia, of which we have here a draving, and the figures of ships taken from Etruscan vases beloug in all probability to a poriod between 500 and 600 B.c. They are the earlicst that $I$ have been fortunate enough to find.

The construction of beak here shorn had in itself manifest disadvantages, which would soon make themselves felt, especially in a sea-way, when the force of the wares, as they tumbled home into the angle formed by the projecting spur, would soon be felt to impede the vessel's way, and to weary the rowers. And secondly, the weight of the projecting spur, especially if any metal was added to it, would be such as to involve a great strain on the fore part of the vessel, and further, being unsupported, it would in the shock of a concussion be liable to break off and endanger the safety of the ship. ${ }^{1}$ We can fortunately trace the improvement that these considerations were sufficient to introduce. We have here a drawing from a coin of Samos, of which the date is given as about 490 B.c., in which the type has altered so far that the angle before noticed has been filled up by carrying on the waling-pieces that strengthen the hull of the vessel, and filling in on a gradually.rising and receding curve, while from the point at which the upper waling-piece projects beyond the stem, the stem itself is carried up and forward in a bold line, so as to meet and divide the crests of the mares that might rise to that height. 'The whole structure marks an advance in the seafaring habits of the Greeks. The vessel thus constructed at the bows had a general resemblance to a pig's face, or, to speak more artistically, a boar's head; and it is interesting to find an historical incident connected with this matter. Herodotus tells us (Book III, 59) that the Samians who had risen against the tyrant Polycrates, when deserted by the Lacedæmonians, who had come to their aid, after making a raid on the island of Siphnos (and extracting one hundred talents of gold from the pockets of the inhabitants), settled in Cydonia, in Crete. There they flourished till they were beaten by the Eginetans in a sea fight, who, after the rictory, cut off the bows of their ships, which were shaped like a boar's head, and placed them in the temple of Athene, in Egina. The date of this battle is about 516 B.c. The coin is of somewhat later date, but it bears witness to an improvement in shipbuilding which is thus confirmed incidentally by Herodotus; for the cirenmstance rrould hardly have been mentioned if the shape had not been regarded as a novelty. That the Samians themselves claimed it as their own invention and were proud of it, may be inferred from the fact, that it became with them a national symbol, which survived on their coins eren as late as the first century B.c. That it was recognized as such by the other Greeks, and especially by the jealous Athenians, may be gathered from the account given by Flutarch in his Life of

${ }^{1}$ Compare the instance giren by Polsbius, Book XVI, in the battle between Philip and the Rhodians. 
Pericles, wherein he tells us that the Samians taken prisoners in the war which ensued upon the Samian rerolt in 440 B.c., were branded by the Athenians with a "Samena," as it was called, and explains, that the "Samena" was a kind of ship invented by Polr. crates, and was boar-faced in the currature of prow (ivompopos ;o oifojea). If Polycrates was the inventor, it is interesting to notice that he was closely connected by friendship with Amasis, the Egyptian king; but, at the same time we may obserre a development towards the same type upon coins of Phaselis, of a date quite as early as that which we hare just noticed. I would also obserre that an intermediate stage, showing the improvement begun, bat not yet fully carried out, is discernible in the representations of some of the pirate vessels on the Etruscan rases.

I may mention at this point that, so far as we can gather from coins, the Persian and Greck types of beak seem here to part company. The coins of Pharnabazus of between 400-380 B.c. show, with very little modification, the type we have noticed in the earlier coin of Phaselis. Have we not here a clue to the maritime superiority of the Greeks over the Persians; progress in adaptation of means to ends on the one hand, prejudiced adherence to that which has led the way to success in past time on the other? A nation which cannot invent for itself, or, at any rate, assimilate the inventions of others, can nerer command the seas.

The Samian invention was not in anj way a perfect one, but it was a real step in construction. That it was somewhat clumsy may be inferred from the remark that Plutarch makes that the "Samæna" was "low in the fore part and wide and hollow in the sides, making it "light and expeditious for sailing." The Athenians when their necessities had forced them to become a naral people, produced a vessel calculated for greater speed and ramming power. Fortunately, we hare a representation of part of an Athenian trireme which enables us in some measure to judge of the progress made. The details of construction are clearer than in the representation given on coins. Here is a ressel built for speed, with lines as fine as those of a racing facht.' 'The lowest waling-piece is carried out to a sharp point, which rises at some little height above the water, so. that in smooth water it would always be clear. The entry is extremely sharp and fine, and gives at the first glance the idea of great speed. Such a ressel was well adapted for the Athenian tactics, which were based on rapidity and dexterity of movement. But the reak points are evident. A bow so constructed was capable of piercing the side of any ressel of the period to whieh it belonged; but as I have noticed in my previous lecture, the Corinthian shipwrights accurately gauged the force of impact with which a ressel of this Juild was capable of delivering a blow, and procecded to strengthen the bows of their ships in such a war as to be able, not only to withstand the full force of such a blow, but to cripple the vessel that delirered it. This they effected by shortening the projecting prow and making the bows of their ressels much thicker and stronger, and at the same time by greatly strengthen.

1 See Plate XX. Athenian galley with rowers. 
Jotunat R.U.S. Institution

Val 20

P1. XXI

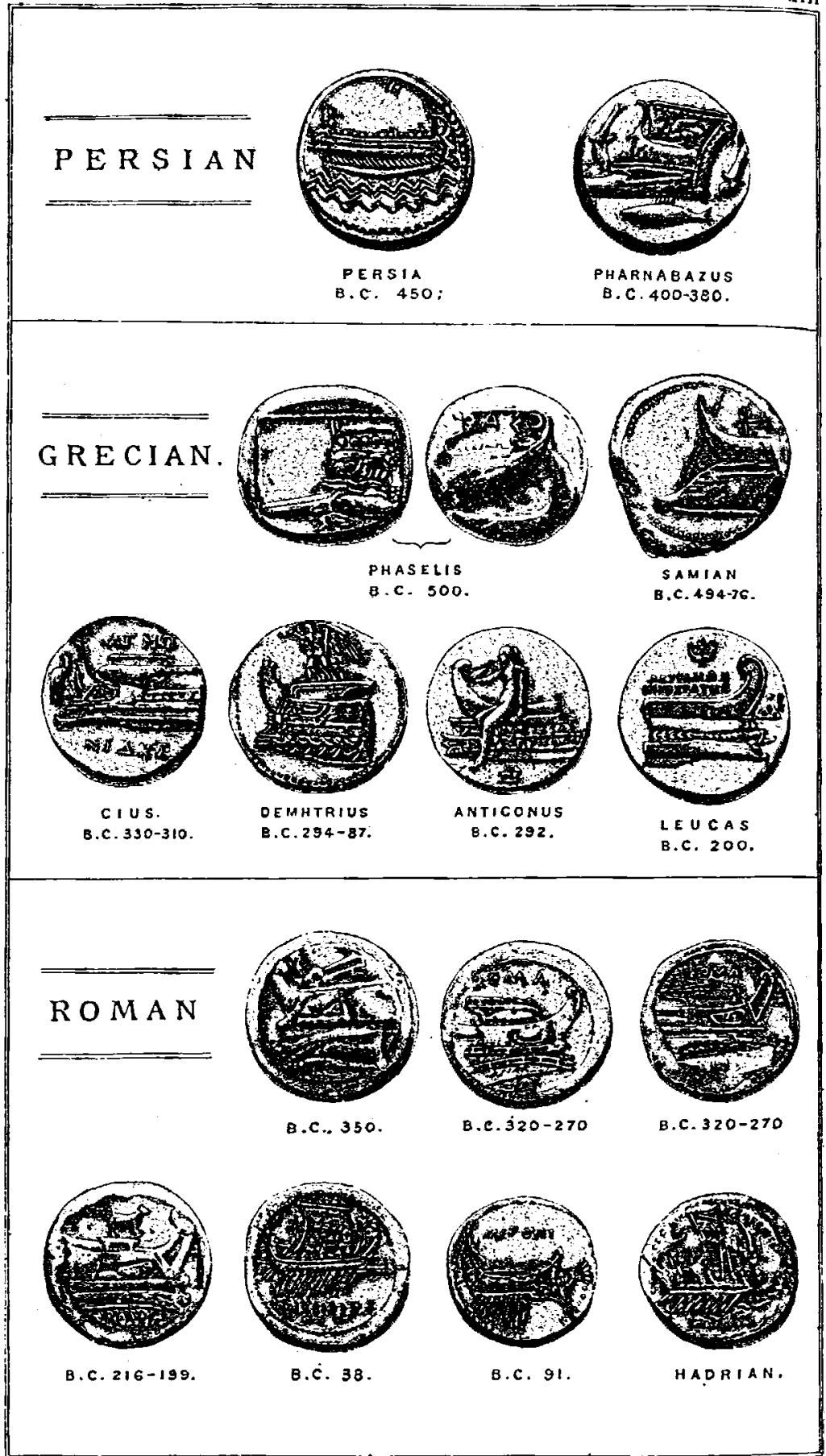

J.Jobbins 
ing the catheads ( $\dot{\varepsilon} \pi \dot{\omega} \tau i \varepsilon \in s$ ) that projected on either side of the bow. These catheads were constructed of heavy balks of timber, supported both from within and from without by wooden stays of about nine feet long, stretching from under them to the sides of the ship. These when the attack of the enemy's vessel was received "stem-on," which was, as we shall see hereafter, the form of attack which they took care to invite, broke up the forecastle and upper parts of the hull of the Athenian ressels so as to make them unseaworthy. The erent, as we know, answered the calculations of the Corinthians, and from that moment the Athenian ceases to be the representative type of Greek war-vessel.

Yet the type itself is not wholly lost, and I think I mas venture to say, though the subject is obscure, and I have not had all the opportunities that I could wish of following it out, that the subsequent Greek types oscillate between those of Athens and of Corinth. For it was only in close waters where there was not roon for maviouvring at large, that the Corinthian build was certain of its advantage. In the open sea, speed was still indispensable for victory. Hence the question for the shipbuilder in the construction of the prow of his vessel was how to combine speed and strength. The invention of larger vessels with many banks of oars gave greater speed and greater force of impact. To meet this, heavier timbers were used in construction, and the waling-pieces became thicker and the bows of the ressel were not unfrequently armour-cased with bronze. The beak, no longer projecting so far as in the Attic trireme, was armed with three teeth so as to intlict a crushing blow without incurring the danger of being entangled in the enemy's vessel, a danger which often proved very real in action, as the following instances show:In the conrse of the battle of Salamis, an Eginetan vessel rammed a Samothracian vessel. The Samothracian marines were expert in the use of the javelin, and while their own ressel was sinking, and before the Eginctan could clear himself of their wreck, they cleared his decks and boarded and took possession of his ship. Much later in a battle between the Illyrians, 229 B.c., with Acarnanians as their allies agaiust the Acheans off Paxo (Polyb II, 10) the Illyrians used this stratagem against the great quadriremes and quinqueremes of their antagonists. They yoked their light vessels togetber by fours and exposed them sidewass to the onward rush of the enems, who thus became hampered with the wrecks of the innermost vessels, while the Illyrians from the outer ressels at once boarded and swept the decks, and in this way became masters of four quadriremes, and of one quinquereme with all its crew.

It would greatly exceed the limits of a single lecture if I were to delay mnch longer on the construction of the Greek prow. I will merely ask you, therefore, to notice the four instances that I lave selected from coins, for casts of which $I$ am indebted to the kindness of the authorities of the numismatic department at the British Mluseum. The first is a coin of Kius in Bithynia, which shows the influence of the Athenian type very clearly. The bows, however, are not so long or sharp as in the Attic trireme, and there is a sleer downwards in the main 
waling-picce, which terminates in $a$ trident beak. The timber of

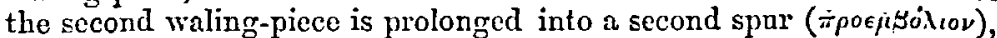
and abore again we see one if not two npper spurs. The epotis is very large and projecting, and shows the influence of the lesson of Syracuse taught a century earlier. The second and third coins are of about orty years later, and belong to the time of the successors of Alexanler. The first, one of Demetrius Poliorcetes, represents, I think, the row of one of his large vessels, for the construction of which te was justly renowned. The trident beak is here prefixed to a jiece of timber, which has a straight run, and projects but little. l'he spars above also are short. . But the Corinthian type is manifest. There is an air of massire strength about the whole, which is wanting in the previous instance. The epotis, the forecastle, and the double timbers of the deck, all combine to give the iden of solidity and weight. . The next instance, from a coin of Antigonus, is more ornate. I would remark only on the prominence of the beak and upper spurs, and the difference of the angle at which the stem is carried upwards as compared with the previous instance. The fourth and last Greek coin is of Leucas, now Sta. Maura, an ancient colony of Corinth. It is of a date when Greek independence was drawing nigh to its extinction, and the Romans were already masters of the sca. Compare this type with that of the Athenian of two centuries before, and the difference of build is at once apparent.

Let us now pass from Greek to Roman prows, of which I have selected for comparison seven instances from coins in the British Musenm. Of these, three belong to a period previous to the first Punic war; and I mention this, as it has been often too readily assumed that the Romans had never engaged at all in maritime warfare before that time. The treaty however with Cart'age, which was made in the time of the kings, proves that even as early as the fifth and sirth centuries they were familiar with the sea. The appointment of Daumviri Navales, officers charged with the duty of equipping and repairing the fleet, an office which existed before the year 311 B.c. (as we find the right of election of these officers then transferred to the people)-is in itself sufficient evidence of the existence of a fleet. The coin, of which we have here a drawing, dates from the jear 350 B.c.; and so far as can be distinguished from the rough outlines which it presents, is of a somewhat different type from the Greek, much more rude and bluff, the stem carried forward at a sharper angle to the water, and terminated in a curved acrostolion of much shorter and stouter build than those observed in the Greek types. If the Romans did 'borrow from the Greek cities of Italy in the matter of naval construction, we may be sure that they departed from their models freely to suit their own ideas of practical utility. In the troo next instances, which belong to the half century preceding the first Punic War, we have two varieties of construction belonging to the same period. In the one, the beak is depressed, and the timbers that support it are of less thickness in themselves, but compacted together by means of cross-pieces. It seems to represent an attempt at a construction which should save weight without sacrificingr strength. The 
other is more decidedly Greck in type, showing a single piece of timber carried out straight into the trident beak, and similarly a

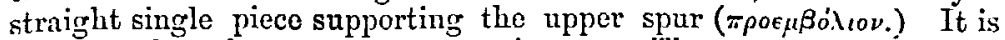
probable that these vessels were triremes. They may have belonged to that flect which was forbidden by the treaty contracted with Tarentum about the year 303 s.c. to sail beyond the Lacinian. Promontory, or to the fleet of ten Cataphract ships which, under L. Cornelius in ¿82 B.c., riolated that treaty, and being attacked by the Tarentines, suffered a loss of four vessels sunk and one captured. The long struggle, however, of the Samnite wars had engrossed the attention of the Romans almost completely in military matters ; and the very terms of the treaty, the infraction of which met with such signal chastisement, show that their efforts. by sea were of sccondary consideration to them. The war with Pyrrhus succeded, and at the opening of the first Punic war in 264 B.c. Rome was practically without a fiect. Her armies marched by land to. Rhegiam, and thence, in the absence of the Carthaginian flect, crossed the narrow strait by such transports as they could collect from their Greek subject cities. It was not till the Carthaginian fleet, ravaging the coast of Italy, brought home to them the real conditions of the contest upon which they had entered, that the Romans turned their attention in real earnest to the sea. Hitherto the conquest of Italy had oceupied their thoughts, and Italy was to won by land. But the first Punic war was the commencement of a struggle for a wider empire, the empire of the ancient world. No empire is erer won, no, nor ever maintained, without the mastery of the highways that are the means of communication; and the first step to the empire of the ancient world meant the command of the Mediterranean. I : un therefore tompted here to dwell upon the construction of the Roman ileet in the tirst Punic war as an event unparalleled in history, and surely one of the gravest significance, if by a sudden effort a purely military nation conld take to the sea, and with the aid of a new mechanical contrivance, in a few years ntterly crush and practically extingrish, not only the flects of the first maritime power in the world, but the very spirit which made those fleets formidable. Hannibal may rarage Italy, but he has reached Italy by land and not log sea. He may march to the very walls of Rome, but no Carthaginian ficet dares to support him at the mouth of the Tiber. Wo hear of one or trro skirmishes, but of no great naval action. It is not too much to say that from the close of the first Punic war to the days of Ricimer, no foreign nation dared to contend against; the maritime power of Rome. Actium indeed decides the fate of thr? world, but Actinim is Rome arrayed against herself.

The transference of maritime dominion is closely connected with the subject immedintely under our consideration, the use of the ram. We have already seen how, by the improrement in the construction of the borrs of their vessels, the Corinthians and Syracusans were able to paralyse the superior nautical skill of the Athenian. Brute force, thickness of timber and armour-plating, patient atiention to detail, and a steady perception of the end in view, prevailed over élan and seamanship and quickness of mancuvring 
power. The same lesson is now taught again upon a larger scale, and with far more momentous results to the world. The Romans had no fleet,--perhaps a few triremes, but nothing that could keep the sea against the Carthaginian quinqueremes, ships of five banks of oars, which were the line-of-battle ships of the day. By chance, in the jear260, one of the Carthaginian vessels of this rate was driven ashore and captured by the Romans. With the practical sagacity and unswerving energy of purpose which distinguished them, they determined to construct a flect upon this model. The timber was felled, the shipwrights set to work, and, within two months of the time when the trees were -standing in the woods, a fleet of a hundred ressels, each 168 feet.long and of 534 tons measurement, had been constructed. Not only this, but the future crews meanwhile were placed on framework set up upon the land, and there and then prac. tised in the motions of rowing to the roice of the keleustes. When all was nearly ready, the Admiral, $\mathrm{Cn}$. Cornelius, set sail in advance with seventeen ships, leaving orders for the fleet to follow. He sailed, and within a few days was taken, ships and all, by the Carthaginians. Meantime the rest of the flect was under way. The ships were badly built, and terribly slow, as might have been expected. Defeat was a certainty; but some ingenious spirit suggested to Duillius, who now assumed command, the construction of a novel engine of warfare, destined to render useless the rams of the enemy. This contrivance was called the "raven" (cortus). As described by Polybius, it was of the following character: at the prow of each ressel was fixed a mast 24 feet high, 9 inches in diameter. This had a pulley on the top. Attached to this mast was a long ladder-shaped construction, with planks nailed across it, 4 feet wide and 36 feet long, with an oblong slit in the cross-planking in the first 12 feet of the ladder. This long ladder or gangwas had a balustrade about the height of a man's knee runuing the whole length of each side. At the end was fastened an iron ciaw, which Polybius compares to the knocker of a door, only sharpened into a point. This had a ring on the top of it, so that the whole was, he says, not unlike the long trays used by bakers in their orens. To this ring was attached the rope by which, as a ship came up for the purpose of ramming, aided by the pulley on the top of the mast, they let the ladder, which thus formed a boarding bridge, fall on to the deck of the enemy's ship, sometimes over the prow and sometimes slewing it round when the attack was on one side. 'l'he weight of the boarding bridge falling drove the sharp iron spike into the planks of the enemy's deck, and so bound the two vessels together; then the marines, if the vessel was prow to prow, rushed two abreast over the bridge; if alongside, boarded from all parts together. Once the trained soldiors of Rome had gained the deck of a Carthaginian ressel, and there was but little chance for her. "The "mere "rabble" (as Niebuhr. oalls them) of an African crew could do nothing to withstand such a foe, for the crew of the Roman quinquereme seems to have consisted of 120 soldiers, in addition to 300 rowers and seamen, a far larger proportion of marines than that employed in the Greek ressels. 

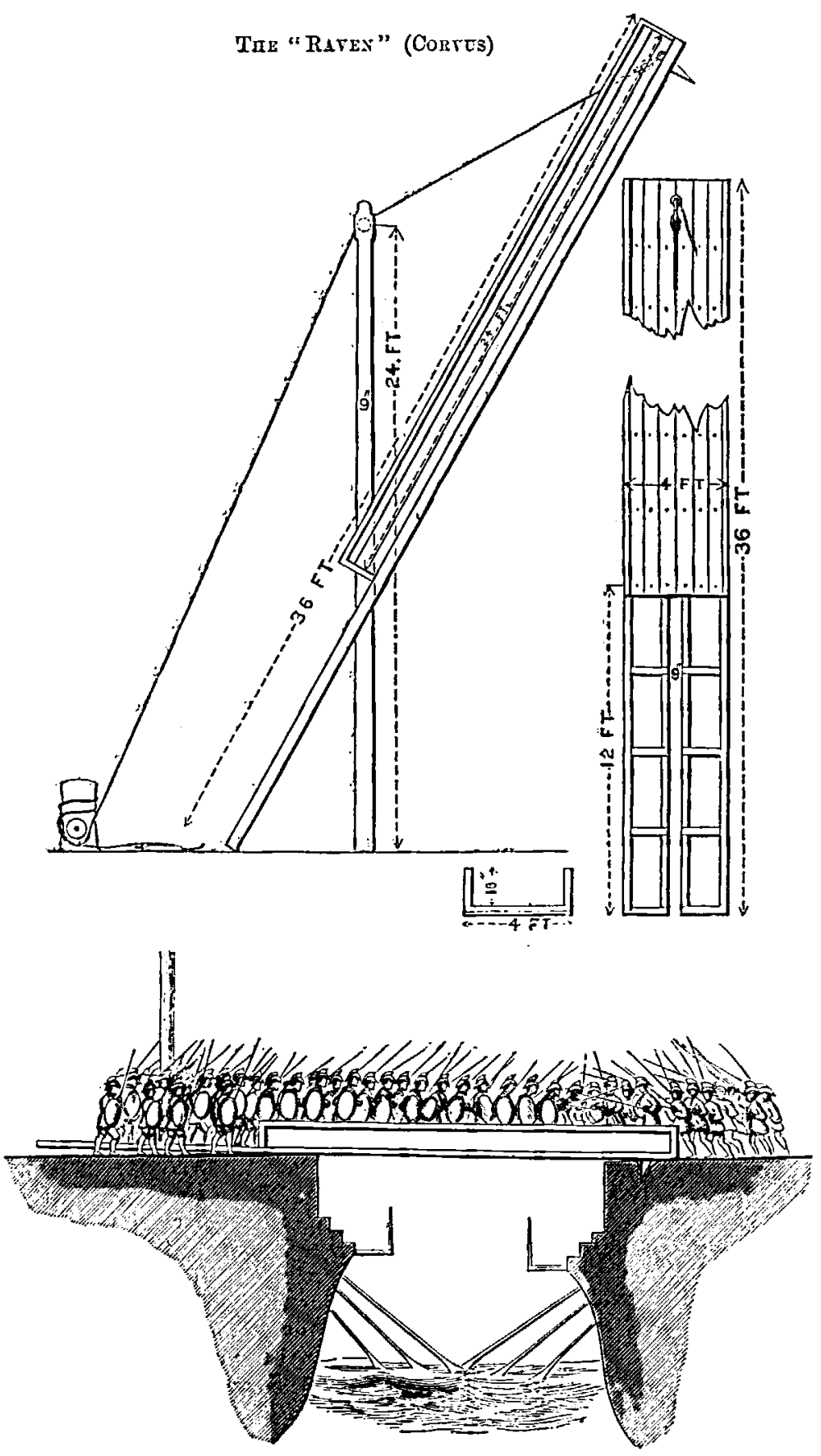
The result of the first naval engagement proved clearly the sound good sense of Duillius in adopting the new invention proposed to him. Unless he could redace the conflict to something like land-fighting, there was no chance whatever for him, considering the quality of his ships and his crews as compared with those of the enemy. The "corvus" provided him with the means of using his real strength. The two fleets met at Myla, the modern Melazzo, not far from the Straits of Mressina. The Carthaginians advanced with a fieet of $\mathbf{1 3 0}$. ressels, full of confidence in themselves and contempt for the crers which had learnt to row on dry land, but somewhat puzzled at the masts and long crane-like machines swinging at the bows of the Roman quinqueremes. However, the adranced squadron of 30 ships at once charged, and were almost immediately grappled, and boarded, and taken, including the Admiral's flag-ship. After a short time the remainder of the fleet, finding themselves unable to cope with this norel encine, which robbed them of all the natural fruits of their seamanslip and skill, turned and fled, with a loss of about 50 ships, 3,000 killed, and 7,000 prisoners. This victory was the presage of doom to Carthage and the prelude of maritime dominion to Rome. The ram henceforth, though still formidable, had no longer the first place ns a weapon of attack. It may be for this reason that in the coin of 216 B.c., of which we have here a drawing, we see it much less projecting, and apparently less strongly supported. Duillius still enjoys well-merited renown, and in the present jear has had his name revired in an Italian ironclad. In his lifetime he was even more fortunate. He alone of all Romans was allowed the unprecedented honour of having a piper to play before him whenever he went out to dinner, and torches to light him as he returned.

In the later Roman coins the representation of ressels of war seems to me to erince on the part of the artists a want of interest in naval matters. The types are either grotesque, as in the coin of 91 B.c., or as in the two last instances (one of B.c. 38 and the other of the Emperor Hadrian a century and a half later), indistinct, and fail to convey anj instruction as to the build. In fact, if anything, we. seem to have reverted back to a type resembling the old Persian type, which I have placed side by side for comparison. We may notice also, that in these later Roman coins we have the sail represented, which is not, so far as I have observed, ever found in the case of a Greek manof-war. In the eycs of a Greek, the sail was a symbol rather of flight than of fighting.

We have seen how the invention of the "corras" paralysed the use of the ram. It is interesting to notice how the Athenians, in their distress in the great harbour of Syracuse, where their ramming tactics were rendered useless by the want of space, and by the Corinthian build of bow, at once perceived that boarding tactics were the only alternative left to them by which the victory might possibly be gaincil. To this end they devised an "iron hand" or grappling iron attached to a chain which was to be thrown on board the enemy's ressels and so make them fast. Against this danger the Syracusans provided, by covering their decks with greased hides, so that the grappling irom 
slipped off without gaining a hold. I'he weight of the corvus as it fell prevented any such device availing against its utility.

Of the other weapons of offence used in naval warfare the most important was the "dolphin," a heavy mass of metal, used for the purpose of sinking an enemy's ship. It was hoisted by means of the yard-arm, which was swung round orer the enemy when he came to close quarters. Then the weight was suddenly let fall upon his deck, which it was sufficient to penetrate, even if it did not break right through the bottom of the ship and sink her. We hear also of great beams that swinging from the masts were used as rams against the side, or slung so as to sweep the decks of the foe.

The graphic account given by Casar of the fight of his flect with the Veneti, on the coast of Gaul, introdnces us to the Falces, great spar's with curved stecl heads like a reaper's sickle, with which the cordage of the barbarians was cut, and their ressels which were too unirieldy for rowing thus rendered helpless. In later days we have also the counterpart of modern artillery, the Siphons, from which the terrible Greek fire was launched, rocket fashion, against the enemy. Some of these seem to have been of a very large calibre, others, again, small enough to be carried by a single man.

The sketch will not be complete unless we mention the Turres, towers, the "alta propugancula" of Horace, erected at the bow and stern, and sometimes, if we are to credit the representations on the Golumn of T'rajan, amidslips. These were much in vogne among the Romans, to whose tactics they were subservient, giving a rantage height from which the heary pilum or jarelin conld be thrown down upon the enemy's deck. Agrippa is credited by Serrius with an invention by which these towers could be run up suddenly on coming into action, and were so adapted for the purpose of taking the enemy by surprise.

We may at this point quit the consideration of the armament of the ancient man-of-war and pass to the subject of tactics, properly so called. And first, with regard to the bandling of a single vessel, much in old time, as now, depended on readiness and fertility of resourco in the officers, and especially in the triemarch, or captain. The skill of the helmsinan, the inspiriting voice of the kelenstes, the alertness of the stoicharchs, or captains of the banks of oars, were scarcely less important; but above all, upon the training and condition of the oarsmen, upon the efficiency of the motive power of the vessel, depended the chances of victory in single combat. It was in the perpetual training and hardenirg, under circumstances in which real danger supplied the motive for energetic action, that the free crews of $A$ thens and her allies attained to that excellence which secured to her the sorereignty of the Esean for so many jears. It was the want of training and the refusal to endure hardships that cansed the Ionians to be disastrously defeated by the Persians at the battle of Lade, aud delayed their chanees of freedom for fourteen years. The story of Dionysius the Phocæan is interesting and instructire. There, off the shore of the island of Lade, now a hill in the that marshy plain of the Mreander, in the year 491 B.c., four jears before Marathon, was drawn up the crmbined fleet of the Ionians then in revolt against the great king. They 
covered Miletus, their base of operations, and lay facing the north. The Milesians, with 80 ships, held the right wing, the place of honour, and next to them the Chians with 100 ships, each with 40 picked narines on board. Next were the Lesbians, with 70 , then 43 from the various isles, and last the Samians with 60 on the left. Among the 43 were 3 from Phocea with Dionysius in command, an energetic and able man. In the council his voice was heard telling some home truths, that without practice they could not be perfect, and that with a fleet of 353 sail as against 600 of the enemy, they wanted all the perfection to which they could attain. His advice prevailed. He was placed in command of of the combined flect. Each day he led them ont in column, in order to practice the rowers in manouvring for some hours, and for the rest of the day lie kept the vessels at anchor, and would not allow the crews to land. This last measure, we maj here notice, was a most salutary pre. caution when the enemy were any where near at hand, as the crews, when the ressels were drawn up, were wont to stray away and so to render a sudden embarcation a seene of the utmost confusion. The neglect of this precaution was the cause of the utter destruction by Lysander of the Athenian flect at Egospotami, of the final blow that laid the hopes of Athens in the dust. The Ionians, however, wero made of softer material than their Athenian kinsmen. For seven days they endured the discipline of Dionysius, but then complaints of fatigue and sickness became rife, and the insubordination reached such a pitch that the Admiral was deposed from his command, and the crews had their own way and remained on shore. But a few days afterwards the Persian fleet of 600 sail appeared. The natural result followed. Divided counsels had fostered treachery. They hurried out in column line ahead, and had just time to form up abreast, when the Samians, all but ten, hoisted their sails and left the line. The rest, with the exception of the Chians, who fought bravely, and a few others, among whom was the brave Dionysius, followed their example. Had they perserered in their training, the erents of a few Jears afterwards showed that, although outnumbered, they might have been quite a match for the seamen of the East.

Xenophon, in his short treatise on the Athenian Republic, tells us that the scafaring habits of the Athenians were such that every one knew how to handle an oar, and that the crew of a trircme could be got together with ease at once. In his Hellenics (Book VI), he gives a graphic account of the stern training to which the crews were subjected by Iphicrates, the Athenian Admiral, with a view to getting them into condition, and so increasing the speed of his ships. He left, ho tells us, all his mainsails at home, and setting the smaller suils (áa'iceia) very seldom, used the oar for the entire royage. Whenever the fleet was nearing the place selected for disembarcation for brealfast or dinner, his custom was to pat out further to sea. At a given sigual the whole fleet came about and the ressels raced to shore. The crews of those that arrived first had chuice of ground and water, and were able to get their meals in com. fort, while the laggards fared but ill. By such derices and by constantly practising the formation of different orders of sailing while on 
his way, he brought his crews to a high state of efficiency without, losing time (which was important) in his royage to Coreyra. His diligence and forethought, which are warnily praised by Xenophon, were rowarded by success.

The skill of the captain of each ressel in the manourres of an ancient fleet must have been taxed in no ordinary degree. The number of ressels generally sailing in company rendered the danger of collision considerable. Attention to signals from the admiral's tagship was constantly required. The captain was responsible for ererything that occurred in connection with his vessel, and the story of the unfortunate Scylax, who was lashed to a porthole, with his liead outside and his body inside his ressel, shows that punishment was sometimes summary as well as serere.

The exploit of Artemisia, the famous Halicarnassian Queen, at Salamis, is a type of the ready daring in handling a ressel which the Greeks so greatly admired. Hotly pursued ont of the rout of Salamis by an Attic ship, with friends in front of her and enemies behind, she had the unscrupulous eleverness to run down a Caljndian vessel belonging to the King's fleet, which sank with all hands. The Athenian thinking, when he saw the exploit, that he was pursuing one of his own side, gave up the chase. Xerxes, who witnessed the same, gave her credit for sinking an enemy's ship, and exclaimed that "the " men in his fleet had become women and the women men."

More legitimate was the clerer mancurre of Phormion's captain off Naupactus. The last of the eleven ships that had escaped in the flight from rastly superior forces, he was hotly pressed by a Lencadian ressel. Seeing, as he approached the roadstead, a merchantman lying at anchor some way out, he made straight for her, and turning sharply behind and round her, rammed the leucadian just as sho came up, and sank her, and by this daring exploit, not only saved the remuants of the Attic squadron, but strack the Lacedxmonians with such fear that they stopped rowing, and were ignominionsly defeated by a force only half their number.

A captain's readiness required to be well seconded by his officers,

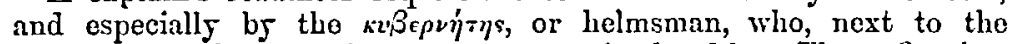
captain, was the most important person in the slip. The sv $3 \in p v i$ in was responsible for the narigation of the ressel. He was the navigating lieutenant as well as steersman. It was requisite that he should be weatherwise as well as waterwise, if one may coin such a word. The adrice of the kvßepvizat seems to have been constantly asked by the admirals in command. We have instances when it was taken and proved of the greatest use, as in the case of Ariston, at Syracuse, who bade the admirals have food brought down to the shore for the crews at noon, so that they might get thoir dinners and then embark suddenly and attack the Athenians, who had returned to their naval camp thinking that work was over for the day. On the other hand, it would have been well for the brave Callicratidas, if he had listened to the advice of Hermon, the Megarian, his $\kappa v \beta \epsilon$ pritis, who realised the value of the odds at Arginusx, instead of making the gallant rejoinder "that Sparta would be no great loser if he died, but that it was base to 
" run away." It was not his personal safety or reputation, but the proper use of the fleet under his command that was the true issue upon which his judgment should have been exercised. The neglect of the advice of experienced $\kappa v \beta \in \rho 2 \eta \dot{j}$;at was, on another oceasion, even more severely punished, when the Romans, in all the confidence of the rictory of Mifla, had begun to fancy that Italia ruled the wares, and Marcus Amilius and Servius Fulvius in the year 255 r.c., took the sea with a magnificent flect of 364 vessels, defeated the Carthaginians, and rescued the remains of the ill-fnted Army of Regulus. Then, returning triumphant in the autumn, in defiance of the repeated expostulations of the $k v \beta \epsilon \rho \nu$ irac they persisted in sailing, though Orion was already showing bis great shoulder above the wave, along the southern coast of Sicily. The storm fell upon them, and of the whole fleet, but 80 hulls surrired the greatest naral disaster, that the world has erer seen, when 106,500 men and 151,656 tons measurement of shipping were at one and the same time sacrificed to blind pre. samption and proud ignorance.

Of the tactics of a single vessel in action, when the ram was the chicf weapon of offence, it is necessary to notice, first, the $\dot{\epsilon} \mu B d \dot{y}$ or impact on the enemy's side or quarter, to effect which skilfully and quickly, was regarded as the acme of success; next, the zporßoi $\eta$, or direct attack, stem on, which was thonght unseamanlike by the Athenians, but adopted, without hesitation, by the Corinthians. It was also of great importance that a crew should be able to back water (avarpovicav) with strength and in time. The diagrams, which face page 535 of the volume of the Journal of this Institution for the jear 1874, of some experiments carried on at Cronstadt, by the Russians, with steam launches, might be taken, mutatis mutandis, as fairly representing the bind of war-dance that two ancient triremes would execute around each other in a prolonged effort. to ram and not be rammed. We do not often hear of vessels of the same rate sweeping away each others banks of oars, for this reason, I suppose, that the projecting parodus, as shown in the model, afforded a protection to them, owing to the angle at which thes were worked.

We have seen with what rapidity an ancient fleet was constructed, in the case of the Romans, in the first Punic war. The Greeks, how. ever, appear to have taken longer to build their ressels, the construction as well as the repair of which was costly. Upon this point we hare amplo details, as regards Athens, but time forbids us to enter upon it here.

At the end of my last lecture, 1 rentured to describe the fitting-out aud departure of the fleet of triremes that carricd the Athenian ex. podition to Syracuse. No mention was then made of the rarions smaller craft that accompanied the morements of an ancient flcet. But, besides the line-of-battle ships, as we may call them, there wcre many lighter ressels ased as despatch boats, as tenders to the flag-ship, as pilot and look-out ressels. Such ressels did not keep out of action when the fleet engaged, but were used to hamper the enemy's oars br ruming under his counter, sometimes even to ram lim when alrendy engaged, or to divert his attention in various wass. And when the 
size of the men-of-war had been so greatly increased that failures in their motire porer were more frequent, and more disastrous when they occurred, the use of the smaller vessels was more and more fully recognized, till, at the battle of Actium, the light Liburnians bore away the palm, and the "tall bulwarks of ships" became a thing of the past to the ancient world.

Foremost in dignity, and generally in size and speed, was the Admiral's flag-ship, known by its pennant or badge (aafárquov). It carricd the vavap $\chi^{o s}$ or Admiral. His second in command was called $\dot{\epsilon} \pi \sigma_{0}$ rodev's. From the admiral's flag-ship the signals were given and probably repeated by all the ships of the feet. These seem to hare been generally made by flags, the red sagum or cloak with the Romans being hoisted as a signal for action. What the principle of their signalcode was we cannot now discorer, but it must have been suficiently elahorate, to judge by the indications that we have remaining.

It is interesting to notice that the raising of a shield appears, upon tro or thrce occasions, to have been cmployed as a signal, suggestive of the question whether the flashing of reflected rass may not hare been employed thus enrly as a means of communication. The Alcmeonide were accused of having, in this way, signalled to the Persians after Marathon. It was thus that Lysander turned the course of his fleet for Egospotani. It was by lifting up a golden shicld that Demetrius Poliorcetes gare the order to join battle. We hare also an claborate code of fire-signals, given by Polybius, for use on land, by the employment of which any word could be spelt out.

An ancient fleet as a rule did not go far fron land, and generally the crews went on shore for meals, and for the night. The vessels were moored stern to the shore, or drawn up, according as the coast permitted. Herodotus, speaking of the Persian fleet which conveyed Datis and Artaphernes to Marathon, naively remarks that they did not follow the usual straiglt course along the shore round by the Hellespont, but came across the $\mathbb{A}$ gean.

In many irstances, very frequently in the Pelopomesian war, the fleets were accompanied by land forces marching along the shore, and often when the ressels were driven ashore, the soldiers came down to the water's edge to rescue a friend or complete an encmy's disaster. Who that has read it, can ever forget the graphic picture drawn by Thucydides of the actions at Pylos, when, by a wonderful inversion of the natural order of things, Lacedamonians were fighting from the sea, which was not their element, against Athenians on Laconian land, and, when a few days later, after the defeat of the Lacedremonian fleet in the bay, the land forces of the Lacedomonians engaged in a naral action from the land, while the Athenians were land-fighting, as he calls it, from their ships? Not less stirring is the account of the gallant rescne of part of Phormion's fieet by the deroted Messenians of Naupactus, whose lore for their deliverers the Athenians, was increased and quickened by their fierce hatred of their former masters.

In preparing for action, the chief object was to lighten the ressel as much as possible. Hence the great sails and masts 
were put. on shore, and everything that conld be spared as not wanted for immediate use. This practice necessitated the formation of naval camps as immediate bases of operation. A surprise and seizare of such depôts was frequently the object of a-victorious, or even of part of a defeated fleet. Thus, during the battle of Sybota, the Corcyrrean left wing defeats the Corinthian right, pursues it, and burns the camp of the latter, while, all the while, their own centre and right were being disastrously defeated. Similarly, after the battle of Egospotami, Conon, eseaping with nine ships, lands at the headland of Lampsacus, and carries off all the mainsails of the victorious Lysander. The practice of fighting near the land was not unattended with danger. Proximity to the shore not unfrequently damaged the Peloponnesinn flects, the crews of which were more happy on terru firma than on the less stable element, and were thus apt to begin backing when they should have been adrancing. The Athenians, as we hare seen, preferred more open water; and the description of Phormion's manceurres, by which he wished to drawthe Lacedamonian Admiral outside the Straits of Rhinm, at the mouth of the Corinthian Gulf, is well known to the readers of Thncydides or Grote.

The orders of battle adopted by the ancient fleets were, in the carlier times, extremely simple. The fleet sailed generally in a column or columns of divisions line ahead (imi képas). Whien the encmy was sighted, these mored into column line abreast, generally in single line

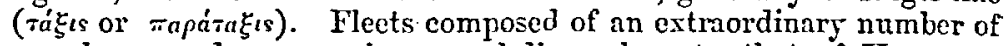
ressels were drawn up in several lines abreast; that of Xerses at Salamis, for instance, in six. The crescent formation was not unusual in the case of a superior force, or one that had its wings protected by the coast. The centre thas refused, the wings could close in and envelope the enems. It was in this formation that the Persians sailed to their firsi defeat at Artemisinm. And in the same, the Lacedemonian Cnemus, tried, off the Achxan Panormus, to draw into action the wary Phormion. The circle was also occasionally adopted, as by the Greeks at Artemisium on the occasion abore mentioned, when, though cooped up in a small space, and face to face at close quarters with the foe, on the second signal they fell bravely to work, and before nightfall had taken thirty of the enemy's ships. The circular formation, however, proved disastrons to the Corinthian fleet, when, fearing the swift Athenian tactics, ther adopted it at the mouth of the Corinthian Gulf, thinking that by showing a front of sharp prorrs on erers side, with their five best galleys in the centre ready to help in any quarter that might be pressed, they would be impregnable. Thes had not yet altered their build, or the result might perhaps have been different. As it happened, that excellent seaman Phormion, the Cochrane of Athens, when he saw their formation, at once concluded that they could not remain firm like infantry on land, which was what they seemed to think possible, but that after a little, their ships would come into collision one with another, especially if the breeze, as was usual in the morning, should spring up and blow from the Gulf. He, therefore, gave orders not to 
attack, but kept his flect in single line ahead, moving round and round, ever closer and closer, till he saw them in confusion. The breeze sprang up with a roughish swell from the castward, and the circle was already in trouble, the oars interlaced, the crews shouting, and all order lost. The moment had arrived, the signal was given, and the Athenians attacked. The Corinthian Admiral's ship was sunk at the first onset, the others showed no fight. A few escaped to Patro and Dymm, the rest were crippled or taken in pursuit.

We hare in Xenophon a minute account of another formation adopted by the Athenians at the battle of Arginuse, which he calls $\dot{\epsilon} \pi i$ dádaryos, which we may describe as two columns of divisions in four lines abreast, each consisting of fifteen ships, with an interval between the first lines of the two divisions filled by ton ships in single line abreast. It was in this formation that the Athenians met the brave Callicratidas, who attacked in single colnmn line abreast.

\section{$11111111111111111111+111111111$}

111111111111

111111111111

\section{$1111\|11\| 1 \|$}

111111111111

111111111111

1111011111111

Athenian Order of Battle at Arginusx.

One other formation remains to be mentioned, as adopted by the Romans in the battle of Ecnomus, near Heraclea, in Sicily, which may be called the wedge(Cuneus). It is described by Polybius in his first book. The Roman Admirals Marcus Atilius Regulus and Lncius MIanlius sailed parallel to each other in two Hexeres six-banked galleys. Their fleet followed in four divisions, arranged in the following order:- The first and second divisions in rear of the two flag-ships in single column line ahead, but so disposed that each ship was in echelon ontwards from the front, thus forming two sides of a triangle, the base of which was filled up by the third division in column line abreast towing the transports, and in rear of this, the fourth division in a similar formation for their protection. Thes thus hoped to present an unbroken front to the Carthaginians, their superiors in speed and in power of manoenrring. The Carthaginian Hamilcar, to oppose them, having divided his fleet likewise into four divisions, drew np three of these in line abreast at right angles to the course of the Roman fleet. The fourth he disposed en potence on his left tomards the land. His object was not only to enclose the wedge, but if possible to draw the two first divisions of the Roman fleet away from the other two, which were hampered with the transports. To effect this, the Carthaginian centre, as soon as the enemy approached, turned in pretended flight and was hotly parsued by the Romans. As soon as Hamilear judged that the two sides of the wedge were drawn sufficiently far away from its base, at a given signal, the Carthaginians turned fiercely on their pursuers. TOL. Ix. 
2xd Postitiox, Carthaginiax Cexme.
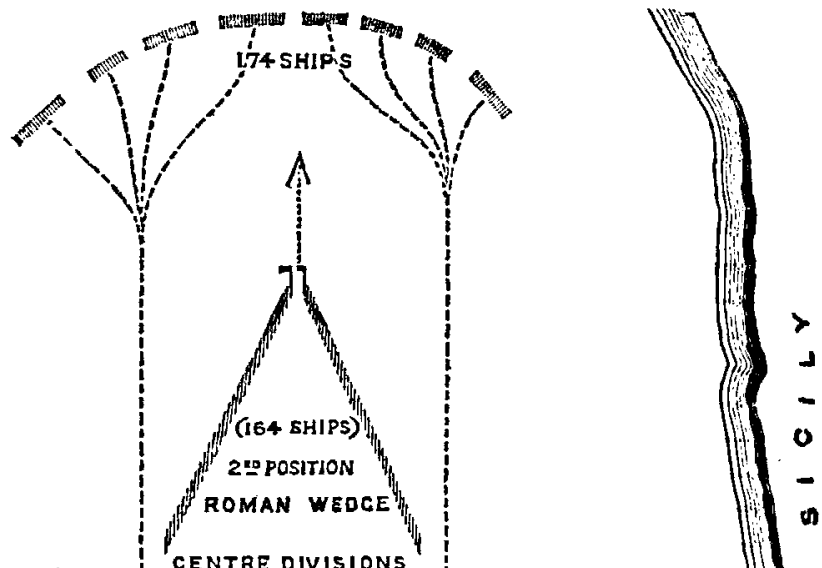

\section{RICHT DIVISION(87 SHIPS) (87ISHIES) DRE DIVISIONS}

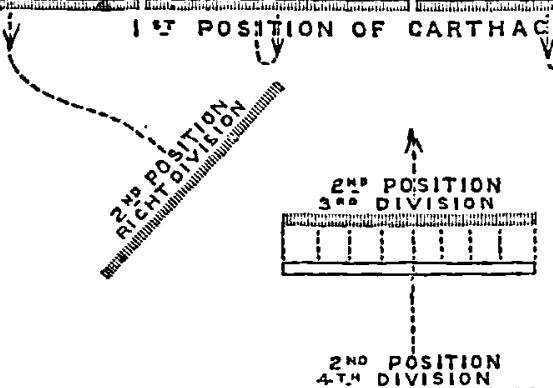

ViNIANS

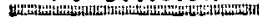
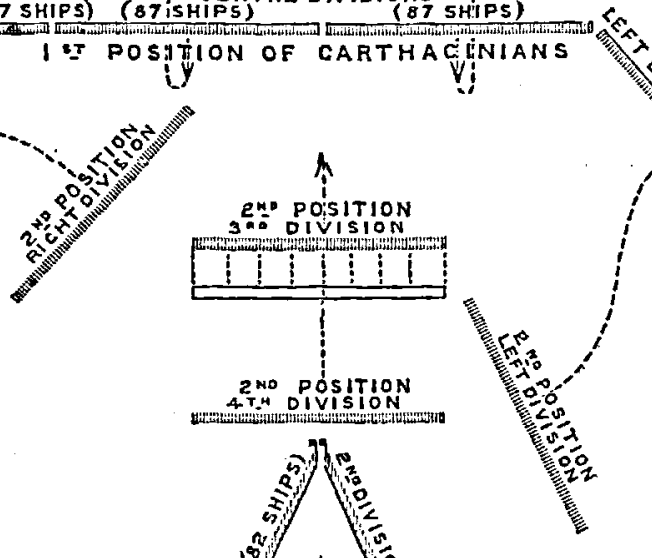

III POSITION
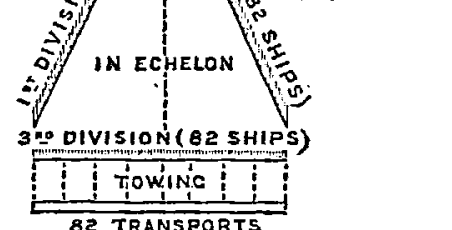

82 TBANSPORTS

-B A T T L E

A

OF ECNOMUS

BET WEEN ROMANS \& CARTHAGINANS B.C. 256.

14 OIVISION (82 SHIPS) 
They found, however, that the wedge formation was still anbroken in pursuit, so far as the two sides were concerned, and that it was, as the Roman Admirals had judged, admirably suited for defence, each ressel facing outward with her next neighbour, ready to assist her if rammed or in any other trouble. Still, if Hamilcar's orders had been obesed by the commanders of his first and fourth divisions, and these had turued upon the open rear of the Roman wedge now sepamted from its base, the victory was assured. These, however, seeing the third and fourth divisions with the transports, and thinking to have an easy victory, engaged with them respectively. Thus three naval actions were going on at one time, in which not less than 680 ships-ofwar were taking part. In the end, the Romans were victorions, the terrible "corvus" showing itself still, as before, superior to the ram. The Carthaginian defeat has its lessons for commanders of divisions or detached squadrons, and its moral is, "Obey orders." The wedge formation in echelon has something in common with the peloton forma. tion of modern days.

Such were the various orders of battle, so far as I have been able to discover them, but these by themselves do not exhaust the subject of the tactics of a flect. For the purpose of attack with the ram two manoenrres were commonly emplojed, named respectively diecplus and periplus. In the diecplus, which accurately rendered, means "the "sailing ont through," the ressels of the attacking flect passed through the intervals of an enemy's line, doing what damage was possible by sweeping off oars, and by a fire of missiles en passant, and then turning with all speed sought to ram the enemy before he could come completely about. In the periplus, a portion of the attacking flcet shecred out of line, and sought to wheel in succession on to the flank of the foe. But for this manœurre cpen water was necessary. In a landlocked bay or harboar, such as that of Syracuse, it could not be employed. Against the diecplus, the practice of sailing in double or triple, or even quadruple lines, was employed, but there was great danger in such formation unless the crews were most perfectly trained, first, because the increase of depth naturally contracted the front, and so laid the fleet open to flank-attacks; and secondly and chiefly, because, as happened to the Persians at Salamis, the sccond line was apt to encroach upon the first, and the third apon the second, and the difficulty was increased tenfold if the lending line retired in disorder on the second while it was adrancing. In fact, for the success of any such combination, the most perfect discipline and silence on the part of the crew was absolutely necessary. The history of the changes in ancient naval tactics is sufficiently well defined. It would not be difficult to trace their development and decline from Dionysius the Phocean to Vipsanius Agrippa, from Lade to Actium. But time fails us, and I would fain ere I conclude speak briefly of tho causes which contributed to the decline of the ancient marine.

'To ourselves, who are familiar with the all-potent steam: slave of the wheel or the screw, it might at first sight seem immaterial whethe the crews, which were the motive power of the ancient manof-twar, were bond $\mathrm{cr}$ free, so long as they had the requisite strengtl: 
and training. But as with the Venetians in later dass, so with the ancients, the employment of slave labour at the oar tended both directly and indirectly to impair the efficiency of the naval service. There were, however, many causes that led to the practice of employing forced labour. First, the absolute discomfort of the crew in a Cataphract ship must have been extreme. In a hot climate, with but very little rentilation, it nust have been exceedingly trying to take pirt in a laborious mechanieal toil with perhaps some hundred or two of human beings stark naked, and packed so closely that there was not room, as Cicero says, for eren one man more. The heat, the smells, the toil, must have been terrible; to any one undergoing it against his will so terrible as to suggest that even death itself were better than such drudgery. A dull dead feeling of despair must hare crept orer many a crew in such a case, and though the lash might keep them going under ordinary circumstances, such spirits could not be relied upon in times of emergency.

In proportion as the size of the vessel was enlarged, so the number of the crew was increased, and we have seen that it is probable that in the larger vessels, the ordinary space allowed per man for the rowers was reduced from 8 to 7 square feet. The conditions of the service were therefore rendered worse and not better by the advance in naval architecture.

Besides the question of discomfort, the actual danger was very great. The crews were liable at any moment to be drowned or burnt, or in the case of defeat, butchered by the victors, perhaps, as at Sybota, deliberately in cold blood. Conceire the moment of conflict and its horrors, when the sharp-pointed beak came crashing through the timbers, smashing them right and loft along with the helpless mass of human beings, while the water followed swift upon the blow, perbaps just giving time to the Thranites to swarm up upon the deck, while the helpless Thalamites were drowned at once.

It is not to be woudered at that such a service should become unpopular, and that in the deficiency of free labour, which became all the more costly as the conditions ander which it was to be employed became less iuviting, recourse should lave been had to slaves. Hence, perhaps the glory of the trireme has been greater than that of the larger ressels that superseded it, for the great feats which it performed were wrought by the hands of free men fighting for their country or its allies, or else volnntarily giving their serrices for pay. At the time of the Peloponnesiar war the pay of an ordinary oarsman, I may mention here, was three obols a day, increased towards the end of the war to four obols, or a little-more than sixpence of our mones. The pay of the Thranites was higher, their serrices being ralued at a drachm, or about ninepence per diem. Raising the pay of seamen was a farourite expedient during hostilities, with a view to crippling the resources of the enemy, by inducing his crews to desert, a practice not without its parallel in modern times. For no purpose was Persian gold more greedily sought after, except perhaps for bribing the chiefs themselves.

The Romans manned their fleets by levies from the lowest orders, 
and by forced service of their allies. Still, the greater proportion of the labour employed by them was that of slares, contributed by free men as substitutes, and it is this fact which perhaps explains the equanimity with which they endured the huge waste of human life which their fleets involved. Hence among the Romans the service on board ship was most unpopular, and we are not surprised to find in the pages of Tacitus the discontent of the Classiarii recorded, who wished to be transferred to a more honourable calling " in spem honoratioris militio." They felt they were despised by their brethren of the legions, and wished to quit a service which herded them with slaves and offered them danger without hope of distinction. Sach were some of the influences which led to the decay of the ancient navies, and at the same time to the obscurity in which the details concerning them are involved. As a rule, the historians (who take endless pains in minutely narrating military operations, for I must except Polybius and Cesar) pass over naval affairs with bnt slight notice, or at the best give slight sketches of such matters in general terms.

It remains for us to institute a short comparison between ancient and modern fleets as regards their tonnare and manning. In this I rely upon the calculations of Graser, for I have not yet had time to work them out for myself. He compares the Attic fleet of the year 330 в c. with the Russian fleet in the Crimea in the year 1854. The tonnage of this he gives at 72,000 tons; the Attic fleet, consisting of 411 vessels, be computes at 98,085 tons. During the next five years the Attic fleet had been increased to 103,577 tons measurement. The present tonnage of the British navy is, I believe, about 300,000 tons, of the French about 200,000 tons in round numbers. The fleet of Xerxes, which we are assured on good authority consisted of 1,207 triremes, must have had, upon Graser's basis, 280,627 tons measurement. The great fleet of the Romans at Ecromus, consisting of 364 quinqueremes, represents shipping to the extent of 193,376 tons. 'These numbers may not be exactly accurate, but they assist us to realise the vast scale upon which these ancient navies were constructed, and forbid us to underrate them.

The multitude of men employed exceeds by far that of modem times. The crews of Xerxes' leet all told, are estimated at upwards of 310,000 men. The Attic navy of the time of Demosthenes required upwards of 90,000 men for its service. The Roman fleets in the first Punic war carried in some instances nearly 120,000 men.

The thought of the emplayment of these vast forces can hardly fail to bring home to us the awful conditions of ancient naval service. What a terrible sight must hare been that storm to which $I$ have already alluded, when the const of Sieily for miles was strewed with the bodies of the dead and with the fragments of the perished fleet! What a spectacle, again, must have been that great Battle of Eenomus, when from the Sicilian coast might have been seen those two great flects, the mighty Roman wedge and the long bent line of the Carthaginians, approaching each other for a struggle to the death. No wreaths of smoke obscured the prospect: the fight with all its pitiless carnage was open to view, and far, we may believe it, over that quiet summer-sea 
re-echoed the thundering crash of the ram, the heary rattling fall of the corrus, the shonts of fury, and the shrieks of pain.

Come with me now, in thought, for a few minutes more. Let ns stand, in spirit, upon the beach of the great harbour of Syracuse, and see the fate of that great fleet, the departure of which, amidst all the entlunsiasm of popular exultation, we witnessed but a short time ago. The scene is now far different. There is no gladness, but sadness everywhere. The roinforcements have come, but the fleet reinforced has been beaten. Athens no longer can claim supremacy on the sea. Her tactics are useless in this close land-locked bay. Worse still, the very mouth of the bay is closed by the enemy; there is no eseape. Only a narrow strip of shore, where the naral camp is standing, can be called our own; the rest is in the hands of the enemy.

"I'ruly we came to beleagner yon city, whose circle of walls is still uxibroken, but are now ourselves beleagured-besieged rather than hesiegers. The months hare been montlus of misadventure and mistrake, and of labour in vain. All has detcriorated, men and material alike-our ships are heary, their timbers are sodden-onr hearts are heary, and onr strength is failing. One more desperate attempt must be made. We mnst change our tacties. Grappling-irons must be used, archers and slingers must crowd our decks. Our old scamanship is gone; our pride, it is now of no arail. Here come the chiefsnot Lamachus. No; he is at rest up sonder, on the hill. He sleeps in a soldier's, not a sailor's grave. No! nor Alcibiades. Where is he? Who knows? Perhaps at Sparta, plotting against his country; perhaps in Asia, intriguing with the Persian. Why did they not try him before we started? His yonth and cleverness might have been of good service ere now to us. But he is gone; he is a traitor; why talk more about him? Nicias is here, the only one of the original three, and the good omen clean taken out of his name. How palc and wasted he looks, scarce dragging his limbs along for pain. Verily, if the Athenians had taken his advice, and recalled him, they would have done well. And with him is Demosthenes, a famous captain, the best of our time. Why send him out too late? Why send him out at all, unless with full porrers to do what his experience dictates? As it is, he is crippled by Nicias, well meaning man, with his superstitions, and false hopes, and dangerous intercourse with Syracusan traitors, who make him their dupe." Such are the mumurings that we overnear, but now the necessity for action silences complaints. The ships are manned, the chiefs address their captains, the captains their crews. They speak with all encouragement; they tell them of home and country to be seen once more, if they win the day; they tell them of the honour of Athens to be maintained. Let us stand aside and see the battle. The fleets are nearing each other. Part of the Athenians are detached to break the barriers that close the harbour mouth. With that the action commences-a fight unparalleled, where, in a narrow space, less than a mile broad, 200 ressels are crowded together in mortal conflict. At first, the Athenians almost succed in loosing the barrier, but the 
Syracusan detachment there is reinforced, and the fight becomes general over the whole harbour. The struggle is long and intense, crews and helmsmen and troops alike vying with each other in doing tlieir best. The land forces of either side, drawn up on the shore, are in agonies, at one time shouting for joy, at another time groaning mith despair, as they witness the victory or defeat of their friends: swaying their bodies to and fro in frantic excitement, following, by gesticulations, the movements of the combatants. At last the fatal moment comes. The Athenians can hold out no longer; they turn and fly towards their camp, pursued brilliantly by the Syracusans, with shouts of triumph. The two great hulks, with the dolphins suspended over the entrance to their naval stockade, protect some of their ships-the rest are ran on shore. All is now over. Demosthenes would fain, with picked crews, make one more attempt to break out; but the men are cowed, their spirit is broken, and they refuse to go on board. Nothing remains but a retreat by land, and so, on the third day, leaving the dead unburied and the mounded uncared for, burning some ships, and leaving the rest to fall into the enemy's lands, the remnants of the Athenian force, numbering still 40,000 men, start on their hopeless march, to end in death or slavery.

Sad is the story of broken pride and hambled ambition, bat its lessons are wholesome and instructive, and the conduct of Athens, in her humiliation, still unyielding, still courageous, sheds a Justre on the dark days of her calamity. Truly, in virtue of this noble spirit, she had a brighter life in store for her in after time, brighter than that which the selfishness of commercial Carthage either deserved or obtained. 